\title{
Quantitative assessment of surface runoff at arid region: a case study in the Middle of Nile Delta
}

\author{
E. S. Mohamed ${ }^{1 *} \mathbb{D}$, Abdel-Aziz Belal ${ }^{1}$ and Mohamed Abu-hashim²
}

\begin{abstract}
Background: Evaluation of surface runoff is an essential factor in the precision water and soil conservation management through their main extreme impacts on soil properties. The natural resource conservation service curve number model (NRCS-CN) model is used to estimate the magnitude of runoff. Collected topographic data is used to explain the effects of slope variation on water retention and surface runoff. Twenty-eight soil profiles are prepared in Nile delta, Egypt to cover different geomorphic units and hydrological soil groups in the study area.

Results: The results revealed that the highest value of surface runoff was distinguished close to the urban area and ranges between 40 and $50 \mathrm{~mm}$. In urban areas, the surfaces are paved and there are no infiltration of water. Consequently, the runoff water directly flows to the storm channels. Runoff values ranging between 30 and $40 \mathrm{~mm}$ occurred at the north of the study area. The sloping surface and the nature of the clay soil contributed to generate more runoff than do lowland areas.

Conclusion: The study presented and tested the hydric runoff estimation based-model on the integrating of hydric balance parameters. The GIS tools analyze and compose these parameters to perform an indirect method for the quantity of water that results in direct surface runoff flow. This method helps to gain clear imaging of the surface runoff risks in the study area.
\end{abstract}

Keywords: Remote sensing, soil types, soil erosion

\section{Introduction}

Water issue is a major challenge in arid and semi-arid countries due to population growth as well as governments' drive to increase agricultural production to achieve a higher rate of agricultural sustainability (Belal et al. 2014; Mohamed et al. 2014; Elkhrachy 2015). Recently water requirements have been increased in Egypt especially with increasing the population rate. Recently, there is a great concern among decision-makers in Egypt about the effects of water scarcity that may affect the country's stability and food security. (MWRIE Ministry of Water Resources and Irrigation, Egypt 2014). Thus, precise water management practices consider one of the main issues and strategies to face the water scarcity and convey the required water for the cultivated lands.

\footnotetext{
* Correspondence: salama55@mail.ru

${ }^{1}$ National Authority for Remote Sensing and Space Sciences (NARSS), Cairo,

Egypt

Full list of author information is available at the end of the article
}

Otherwise, soil runoff is considered another important parameter that should be considered in water management and land degradation (Mishra and Singh 1999; Hawkins et al. 2009; Abu-hashim et al. 2015). Runoff occurred when rainfall and/or the flooding irrigation reaching the earth surface and the soil be saturated, then the excess water starts to flow on the surface. Thus, precise water management practices should be considered to find the most proficient technology to save water and convey it to drought regions and newly reclaimed regions. Furthermore, the flow rate is depending on various parameters; rainfall (intensity and distribution), soil characteristics (texture, infiltration rate, organic matter contents, porosity, and soil aggregation), vegetation cover, and the topographic parameters including slope and aspect (Dunne and Leopold 1978; Morgan 2001). The main parameters that affect the computing of the surface runoff are soil water retention and curve number values NRSC-CN model considered (Michel et al. 2005; 
Mishra and Singh 1999; Hawkins 1993; Agnihorti et al. 2017). Density of vegetation covers effect on the magnitude of surface runoff where removing vegetation cover leads to an increased tendency in soil surface runoff, thereby increase soil water erosion (Mohamed et al. 2015; Michel et al. 2005; Hawkins et al. 2009; Li et al. 2014). Land-use changes and crops types are important factors in the runoff outcome and also effected soil water holding capacity (Mishra and Singh 1999; Hawkins et al. 2009; Abu-hashim et al. 2015). Recently, reliance on GIS and remote sensing has become a key factor for assessing land and water resources and monitoring land degradation and various environments phenomena (Mohamed et al. 2013; El-Zeiny and El-Kafrawy 2017; Gad and El-Zeiny 2016; Hammam and Mohamed 2018; Belal et al. 2019; Mohamed et al. 2019; AbdelRahman et al. 2019). Integration GIS techniques with remote sensing are used as effective tools to resolve and monitoring the potential flood water based on spatial hydrological modeling (Hawkins et al. 2009). Although data of remote sensing was established to initiate the curve number by correlating HSG and LULC with data derived from the NRCS tables GIS has been used as a capable tool for managing, analyzing, and mapping of surface runoff through understanding ecosystem interactions, making it clear for decisionmakers to take appropriate solutions. (Abu-hashim et al. 2015; Soulis et al. 2009; Latha et al. 2012). The establishment of the hydrological soil groups (HSGs) was based on several parameters; soil texture, infiltration, and potential water retention in each pedological entity. The different land-use types had consequences in the surface hydric approach: water quantity, surface runoff, interception of the precipitated, infiltration, and the pedospheric cover.

Many authors have used the curve number model to recognize runoff in different watersheds in agricultural areas, and have been well adapted to suit the multiple uses of surface runoff in other areas.

The main objective of the current work is to integrate soil type data, remote sensing data, using the hydrologicalbased model to estimate the direct earth surface runoff in the middle of the Nile Delta.

\section{Material and methods}

Study area lies between $30^{\circ} 45^{\prime}$ to $31^{\circ} 6^{\prime} \mathrm{E}$ and $30^{\circ} 45^{\prime}$ to $31^{\circ} 5 \mathrm{~N}$, in the middle of Nile Delta it covers Tanta and the neighbor cities and extended aligned between Damietta and Rosetta branches Fig. 1. Study area is like with Mediterranean conditions of climate where the rainfall is seasonal and intermittent and it falls in the winter. However, rainfall recorded in November 2016 about $58 \mathrm{~mm}$ according to the Climatic Data of Tanta Meteorological Station.

Mean and maximum temperature were 18.9 and 24.9 ${ }^{\circ} \mathrm{C}$, respectively. The main landscape of the investigated area is flood plain (Abu-hashim et al. 2015; Mohamed et al. 2015). Operational land imager (OLI) with spatial resolution $30 \mathrm{~m}$ acquired in November 2016. Topographic maps and digital elevation model (DEM) with 30

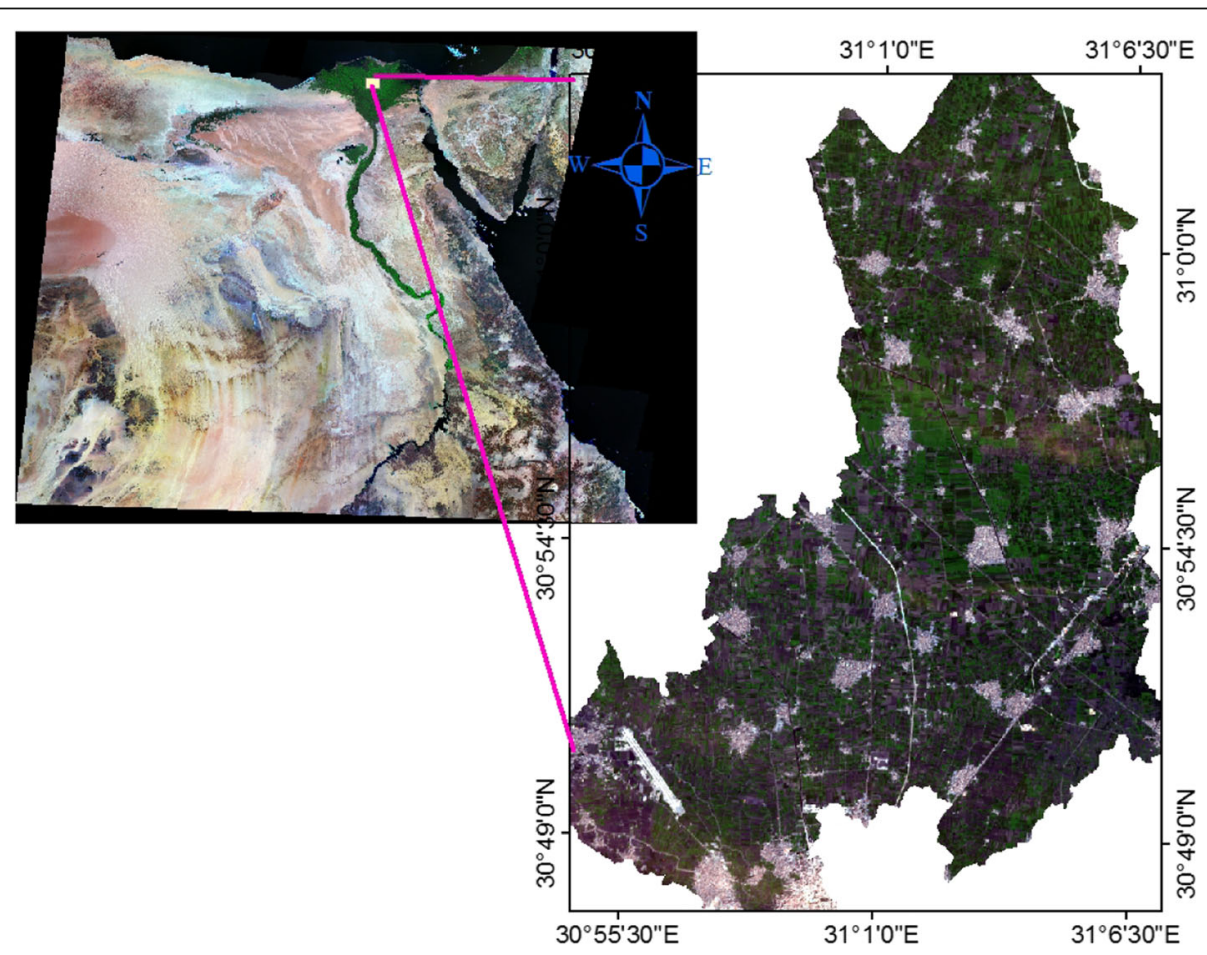

Fig. 1 Location of the study area at Tanta catchment area in the middle of the Nile Delta 


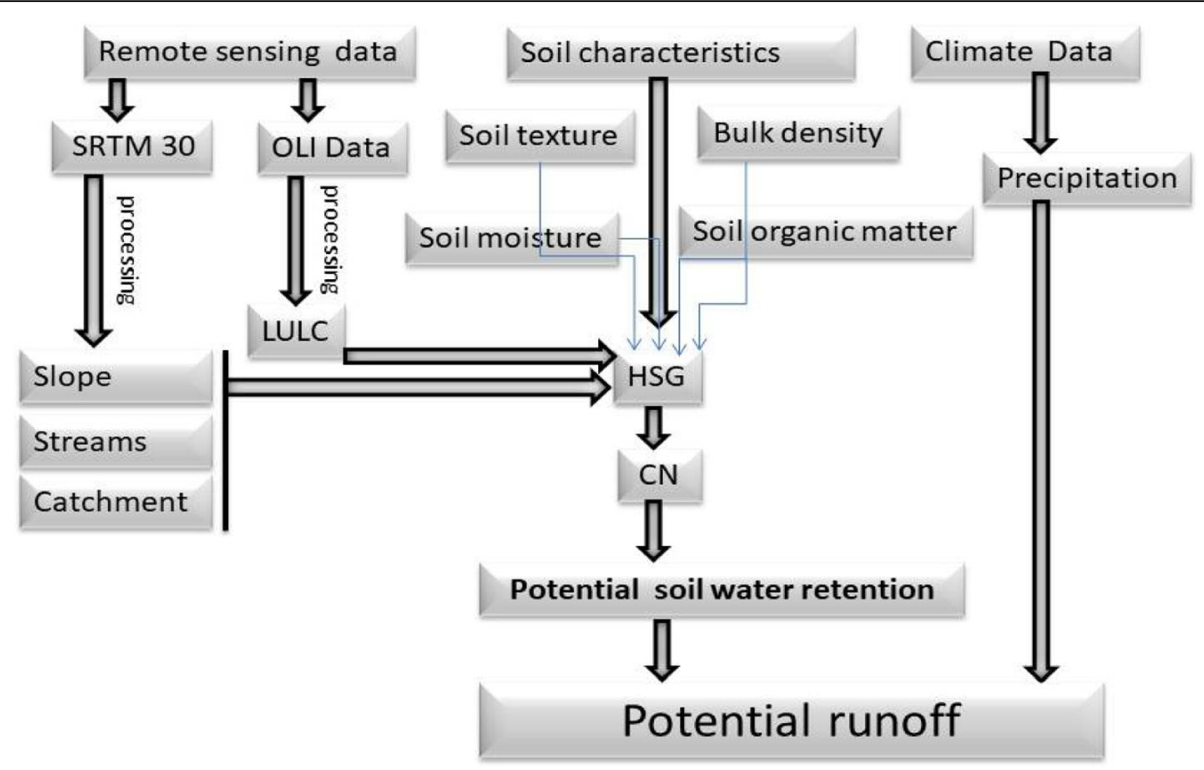

Fig. 2 Flow chart of the method that used to identify the direct surface runoff using the NRCS-CN model and the GIS technique

$\times 30$ m resolution was derived using Shuttle Radar Topography Mission and elevation points were recorded during the field survey by GPS.

\section{characterization of land use}

The differentiation of land used was determined based on the support vector machine (SVM) as described by (Abuhashim et al. 2015; Mohamed et al. 2015) for the Nile Delta. The SVM technique was applied in the image acquired in November 2015 to determine the land use land cover changes of the study area that the SVM classifier provided an accurate method for discriminate LULC.
Watershed delineation and soil sampling

GIS was used for determining the watershed area and network of the streams as well as recognize the subcatchments and their direction that contribute to a single stream based on DEM considering the site morphological properties. Soil samples data covers geomorphological units of study area Fig. 1. The number of sample locations was recognized by calculating hydrologic soil groups, land-use, and soil type for the area and joining them to initiate hydrologic response units $\left(\mathrm{HRU}_{\mathrm{s}}\right)$ using GIS. Soil physical analyses were investigated according to Klute 1986. The study area is characterized by clay loam to

Table 1 Curve number values extracted from published tables listed in NRCS-CN, 1986 (TR-55) handbook manual

\begin{tabular}{|c|c|c|c|c|c|c|}
\hline \multirow[t]{2}{*}{ Land-use } & \multirow[t]{2}{*}{ Treatment } & \multirow{2}{*}{$\begin{array}{l}\text { Hydrologic } \\
\text { condition }\end{array}$} & \multicolumn{4}{|c|}{ Curve number for hydrologic soil group } \\
\hline & & & HSG A & HSG B & HSG C & HSG D \\
\hline Bare soil & - & -- & 77 & 86 & 91 & 94 \\
\hline \multirow[t]{2}{*}{ Fallow } & \multirow[t]{2}{*}{ Crop residue cover (CR) } & Poor & 76 & 85 & 90 & 93 \\
\hline & & Good & 74 & 83 & 88 & 90 \\
\hline \multirow[t]{2}{*}{ Cropland } & \multirow[t]{2}{*}{ Straight row (SR) } & Poor & 72 & 81 & 88 & 91 \\
\hline & & Good & 67 & 78 & 85 & 89 \\
\hline \multirow[t]{2}{*}{ Cropland } & \multirow[t]{2}{*}{$S R+C R$} & Poor & 71 & 80 & 87 & 90 \\
\hline & & Good & 64 & 75 & 82 & 85 \\
\hline \multirow[t]{2}{*}{ Cropland } & \multirow[t]{2}{*}{ Contoured (C) } & Poor & 70 & 79 & 84 & 88 \\
\hline & & Good & 65 & 75 & 82 & 86 \\
\hline \multirow[t]{2}{*}{ Cropland } & \multirow[t]{2}{*}{$C+C R$} & Poor & 69 & 78 & 83 & 87 \\
\hline & & Good & 64 & 74 & 81 & 85 \\
\hline Urban area & - & - & 98 & 98 & 98 & 98 \\
\hline Water & - & - & 100 & 100 & 100 & 100 \\
\hline
\end{tabular}

Poor factors impair infiltration and tend to increase runoff, good factors encourage average and better than average infiltration and tend to decrease runoff 
Table $\mathbf{2}$ Land-use distribution at the catchment area

\begin{tabular}{ll}
\hline Land-use & Area \% \\
\hline Cropland & 59.3 \\
Bare soil & 5.2 \\
Fallow & 27.2 \\
Urban area & 8.0 \\
Water & 0.3 \\
\hline
\end{tabular}

loamy . on the other hand, the soil field capacity varies from 22.8 to $41.8 \%$, while dry bulk density ranging between 1.41 and $1.55 \mathrm{~g} \mathrm{~cm}^{-3}$.

\section{Surface runoff computation}

Figure 2 shows the method that used to assess surface runoff using the NRCS-CN model and GIS technique. SCS-CN model (Hawkins et al. 2009) was used to calculate runoff where it depends on universal water balance as follows:

$$
P=Q+E+\Delta S
$$

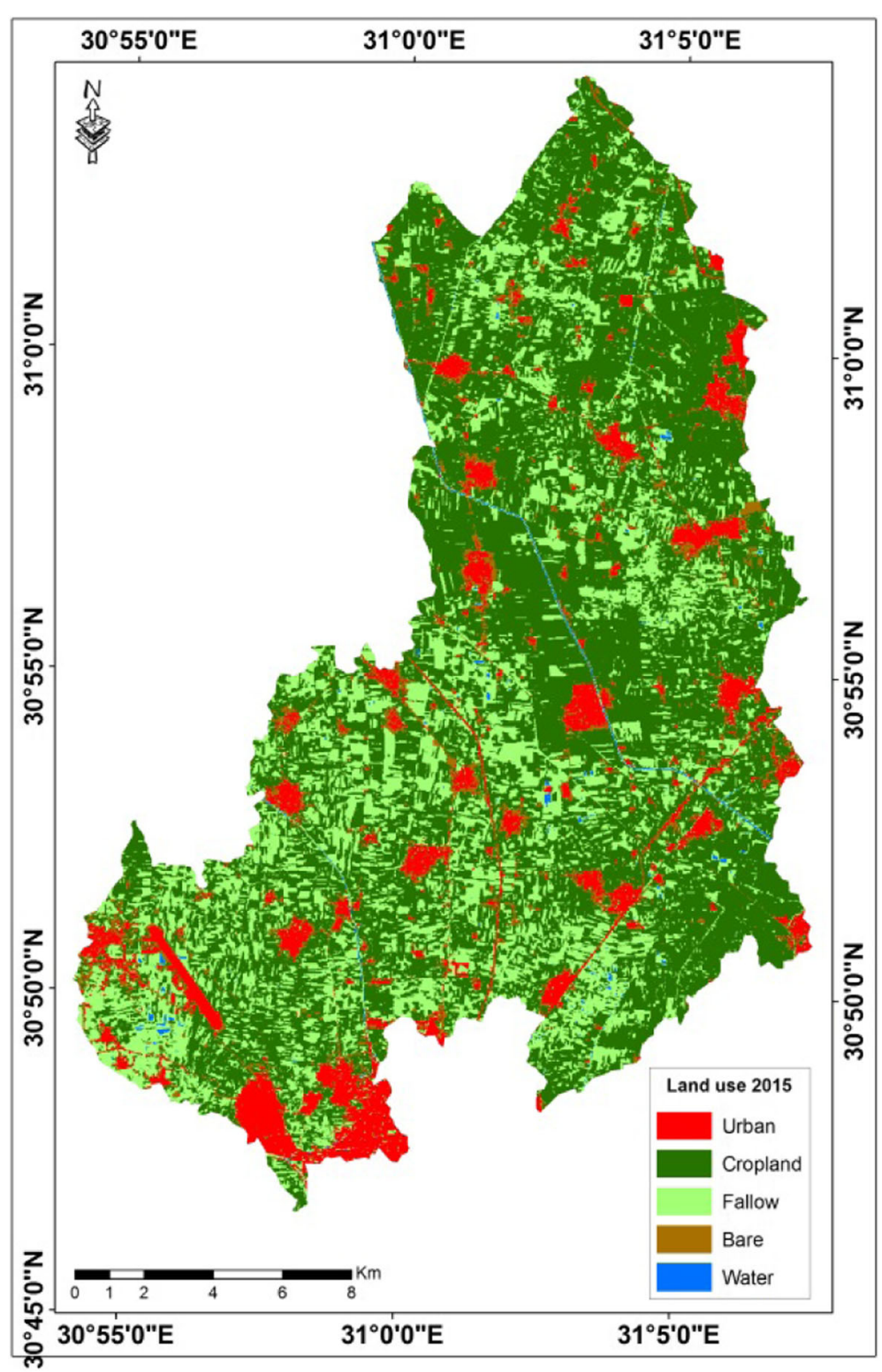

Fig. 3 Land-use types at the catchment area 
That $P$ : precipitation, $Q$ : runoff, $E$ : evapotranspiration, $\triangle S$ : storage term. Natural resource conservation service modified the water balance to the following equation:

$$
Q=P(F / S)
$$

Where $F$ is the actual loss and $S$ is the potential loss. Evaporation of universal water balance equation and storage term has been included in the relation of actual $(F)$ and water potential loss $(S)$. By substituting $F$ (actual loss):

$$
F=P-Q
$$

Runoff was formulated as

$$
Q=P^{2} /(P+S)
$$

Equation 4 explains runoff as a function of precipitation and water potential loss $(S)$ that is identified as retention potential or soil water holding capacity. Since runoff is produced if there is rainfall, the term initial abstraction $\left(I_{\mathrm{a}}\right)$ has been introduced (Hawkins et al. 2009), that is subtracted from the total rainfall to retrieve effective precipitation:

$$
P_{e}=P-I_{a}
$$

Where $P_{e}$ is the effective precipitation and $I_{a}$ is the initial abstraction. $I_{a}$ is all losses before runoff begins that includes water retained in surface depressions, water abstracted by vegetation, evaporation, and infiltration. NRCS-CN approach (Hawkins et al. 2009) is expressed as:

$$
\begin{aligned}
Q & =(P-0.2 \mathrm{~S})^{2} /(P+0.8 \mathrm{~S}) \text { for } P>I \mathrm{a} ; Q \\
& =0 \text { for } P \leq I \mathrm{a} ;
\end{aligned}
$$

The potential water retention $S$ is shown in the following equations:

$$
S=(25400 / \mathrm{CN})-254
$$

Theoretically, $\mathrm{CN}$ ranging between 0 and 100, where $S=\infty$ and $S=0$, respectively.

$$
Q=\frac{(P-0.2 S)^{2}}{(P+0.8 S)} P Q=0.2 S, Q=0
$$

Where

$Q$ is the surface runoff [mm]

$P$ is the precipitation $[\mathrm{mm}]$
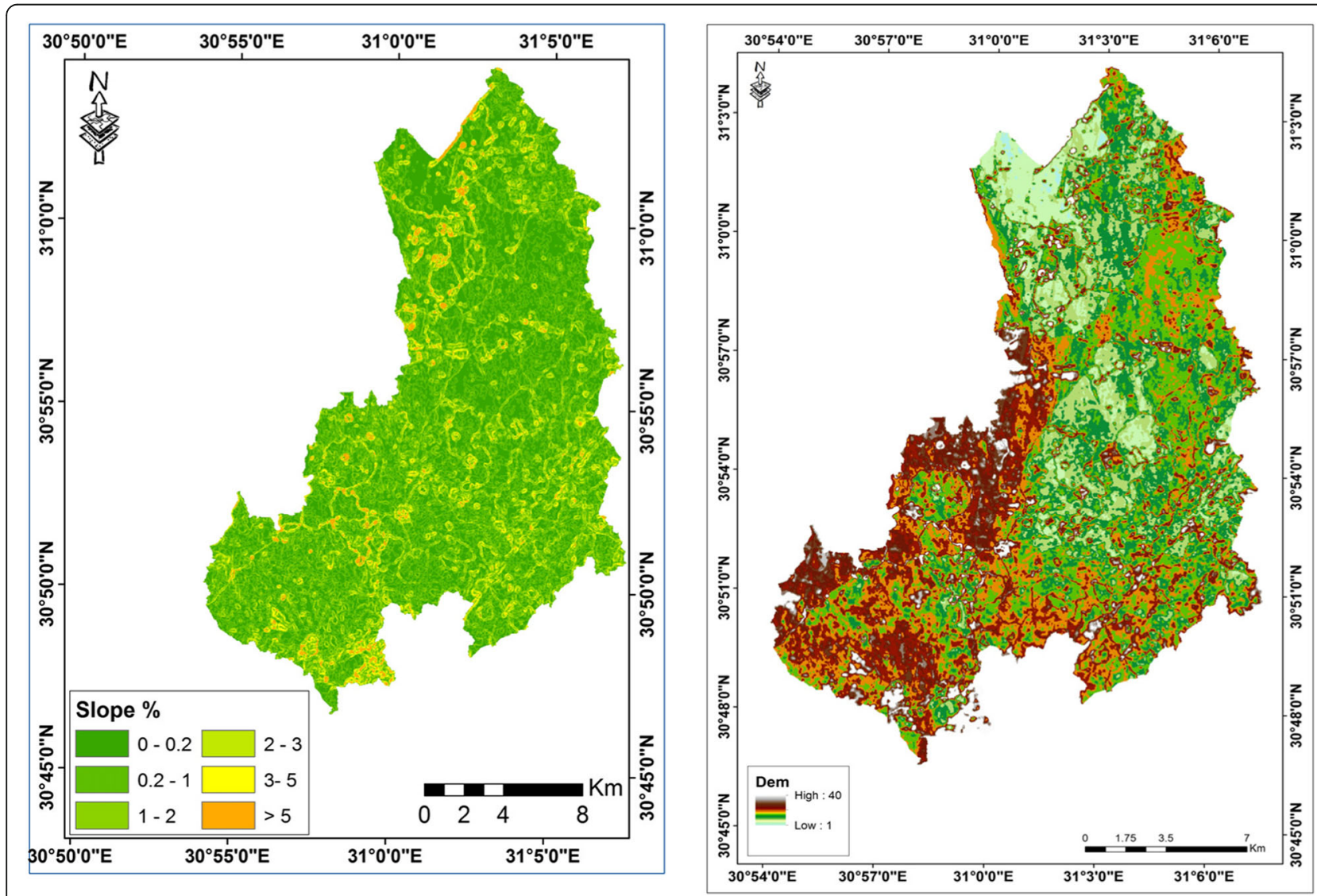

Fig. 4 Spatial distribution of DEM and the slope at the catchment area 
$S$ is the potential water retention [mm]

The calculated monthly summarized runoff, assumed that the precipitation is equal or higher than $0.2 \mathrm{~S}$ (Hawkins et al. 2009). Table 1 shows the curve number handbook values (TR55) were published by (SCS, 1986; NRCS, 2004) and were used in the context of this work. The $\mathrm{CN}$ was identified under the hydrologic soil groups (HSGs), and the land use and land management for each of the soil types in the catchment area.

\section{Results}

The map of LULC illustrated the variation of land use in the study area; croplands occupy an area about $59.3 \%$ of the total area, fallow land covers an area of $27.2 \%$, while urban areas occupy an area of $8 \%$, and bare soil occupies $5.2 \%$ of the total area as shown in Table 2 and Fig. 3.
Soil types of the watershed varied between clay, clay loamy, and loam soil. Saturated hydraulic conductivity varied from 3.9 to $49 \mathrm{~cm} \mathrm{day}^{-1}$. The field capacity ranging between 22.8 and $41.8 \%$, meanwhile, dry bulk density ranging between 1.41 and $1.55 \mathrm{~g} \mathrm{~cm}^{-3}$. Organic matter ranging from 1.2 to 1.6. The area is described by flat to gently sloping where the northern parts of the study area is characterized by flat to almost flat ranging between 0 and $0.2 \%$ except some patches in Fig. 4 . While the southern part is characterized by gradient slope varied from 0.2 to $1 \%$. NRCS-CN model values were calculated depending upon the obtained data of land use land cover, slope, soil types, infiltration rate, and capacity of soil retention of each soil hydrological unit (HRUs). Figure 5 shows curve number map that represents the spatial distribution values of the study area. HSG was

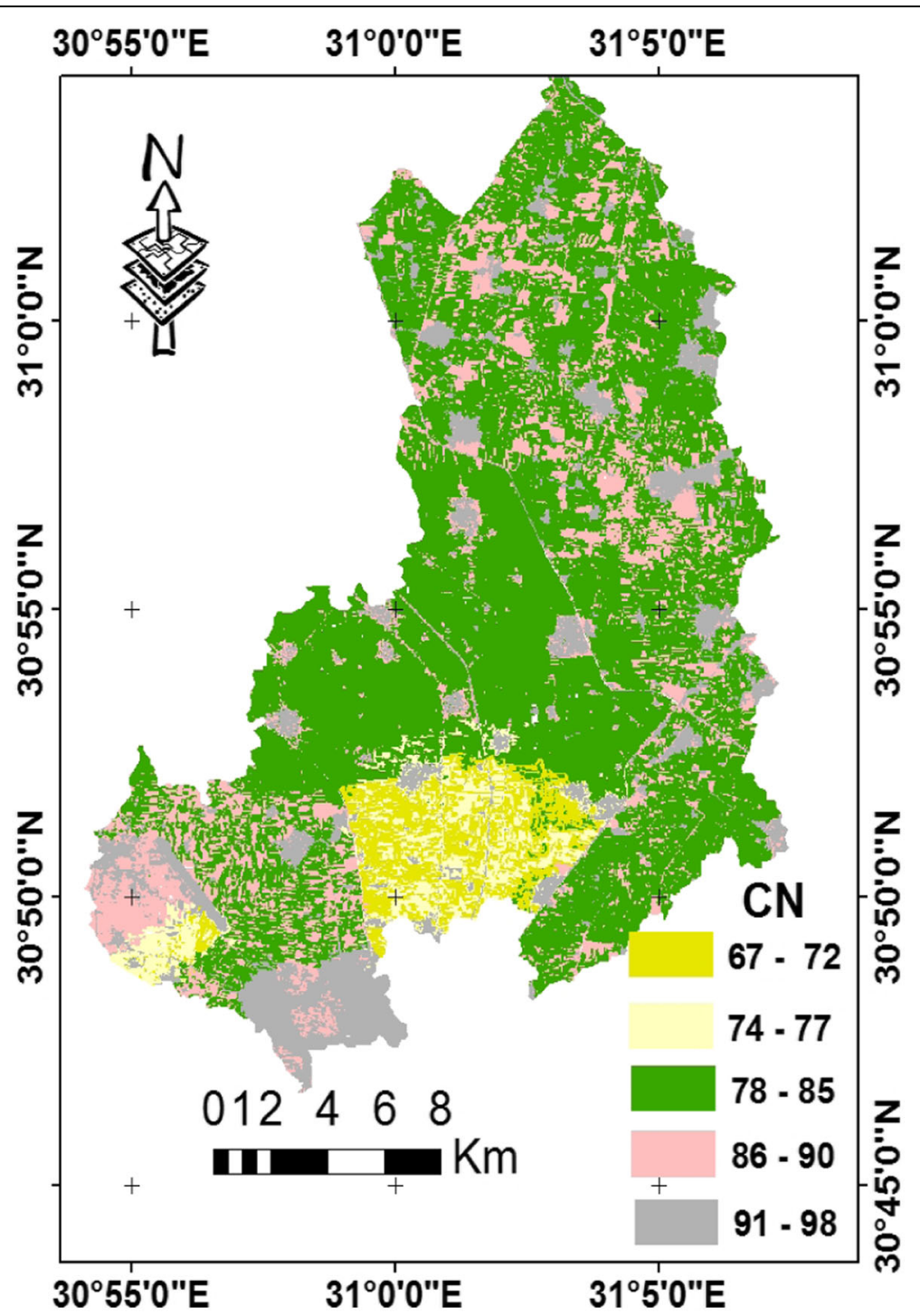

Fig. 5 Spatial distribution for the values of the curve number 
established for the basin based on soil parameters and land-use by using the textbook of NRCS-CN (1972). Thereby, spatial distributions (S) were mainly determined by the spatial variation of LU/LC, slope, aspect, and soil types of the catchment area (Fig. 6).

Direct surface runoff at the study area was calculated using the daily rainfall values. The mean of the rainfall amount was computed using the data of Tanta Meteorological Station (TMS, 1960-2016). The obtained data shows a mean rainfall at the time of soil samples with a value of $58 \mathrm{~mm}$. This value considered as the highest rainfall amount comparing with the same time in the previous year's using Climatic data of Meteorological station in the same region.

The results illustrated that the highest value of the direct surface runoff was distinguished around urban areas where it ranged between $40-50$ and $50-58 \mathrm{~mm}$ where paved surfaces and rooftops did not allow water to penetrate in soil causing direct surface runoff. In addition, the runoff values that ranged between 30 and $40 \mathrm{~mm}$ in the cropland area located to the north of study area, in which the slope tends to generate more runoff than do lowland areas.

\section{Discussion}

Several factors have been integrated using GIS techniques to model surface runoff in the study area. The results show that land use has significant impacts on infiltration rate and soils holding capacity as these results associated with human activities in two directions positive and negative impact. The positive impact was noted in the area demonstrated by good agricultual practice and management, meanwhile the negative impacts were noted in the area characterized by urban sprawl (Hendawy et al. 2019; Abu-Hashim 2011). That the paved surfaces and rooftops did not allow water to

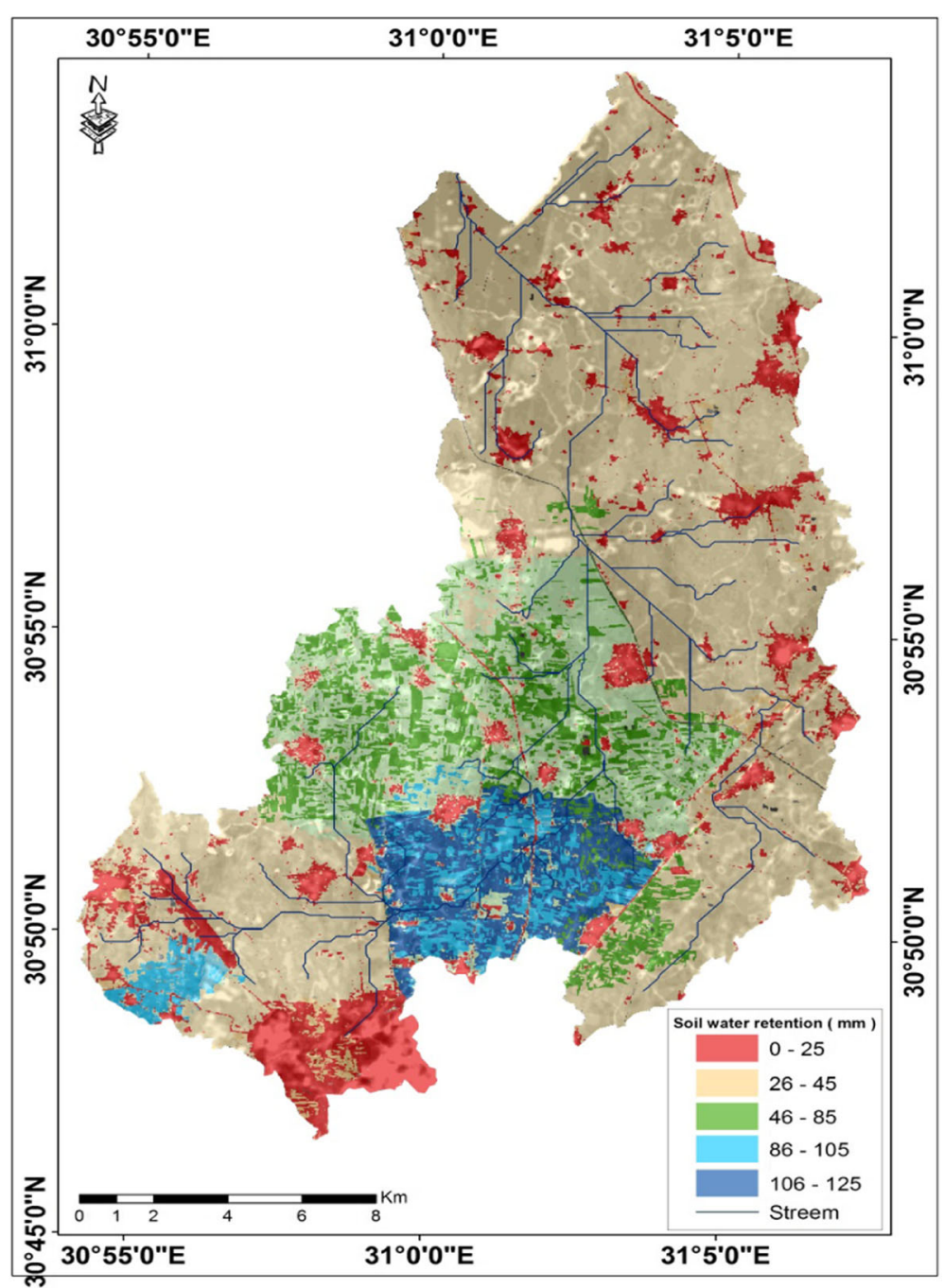

Fig. 6 Spatial distribution of the potential water retention 
penetrate in soil causing direct surface runoff, and these approaches showed with the illustrated results that the highest value of the direct surface runoff was distinguished around urban areas where it ranged between 40-50 and 50-58 mm. Moreover, Hawkins, 1993; Abuhashim et al. 2015 mentioned that enrichment in urbanization activity results in decreasing the soil infiltration capacity which leads to an increase the land degradation. Furthermore, the main phenomena in the middle of the Nile Delta declared that urban areas were sprawled by building industrial communities (Mohamed et al. 2015). Thereby, changes in LULC have distinct impact on direct surface runoff through their influences on the soil water holding capacity (Wahren et al., 2009; Elkhrachy 2015), that urbanization, deforestation, and changes in land-use activities significantly affect the infiltration capacity and the distribution of surface flow. Nevertheless, the most representative results were noticed in the north of the catchment area in which low values of runoff ranging reported from 10 to $20 \mathrm{~mm}$.

The obtained results confirm the fact that soil surface conditions in cropland through infiltration capacity has a direct effect on the surface tendency of the region (Fig. 4). These results correspond well to the findings of (Wahren et al. 2009, Abu-Hashim 2011; Elkhrachy 2015; Hendawy et al. 2019) who reported that land use has a positive impact on soil infiltration. Moreover, the variation in infiltration capacity is largely related to land management and human activity as well as soil characteristics. Because of the reduced surface of the reception basin, the quantity of precipitation was considered to be uniform in the whole basin. The behavior of the basin was simulated in conditions of precipitation of $58 \mathrm{~mm} / \mathrm{m}^{2}$ (current status quo). By applying Eq. (8), two layers were obtained in the evaluation of the direct surface runoff water layer, for each of the two rain categories (Fig. 7). Thus increasing the urban

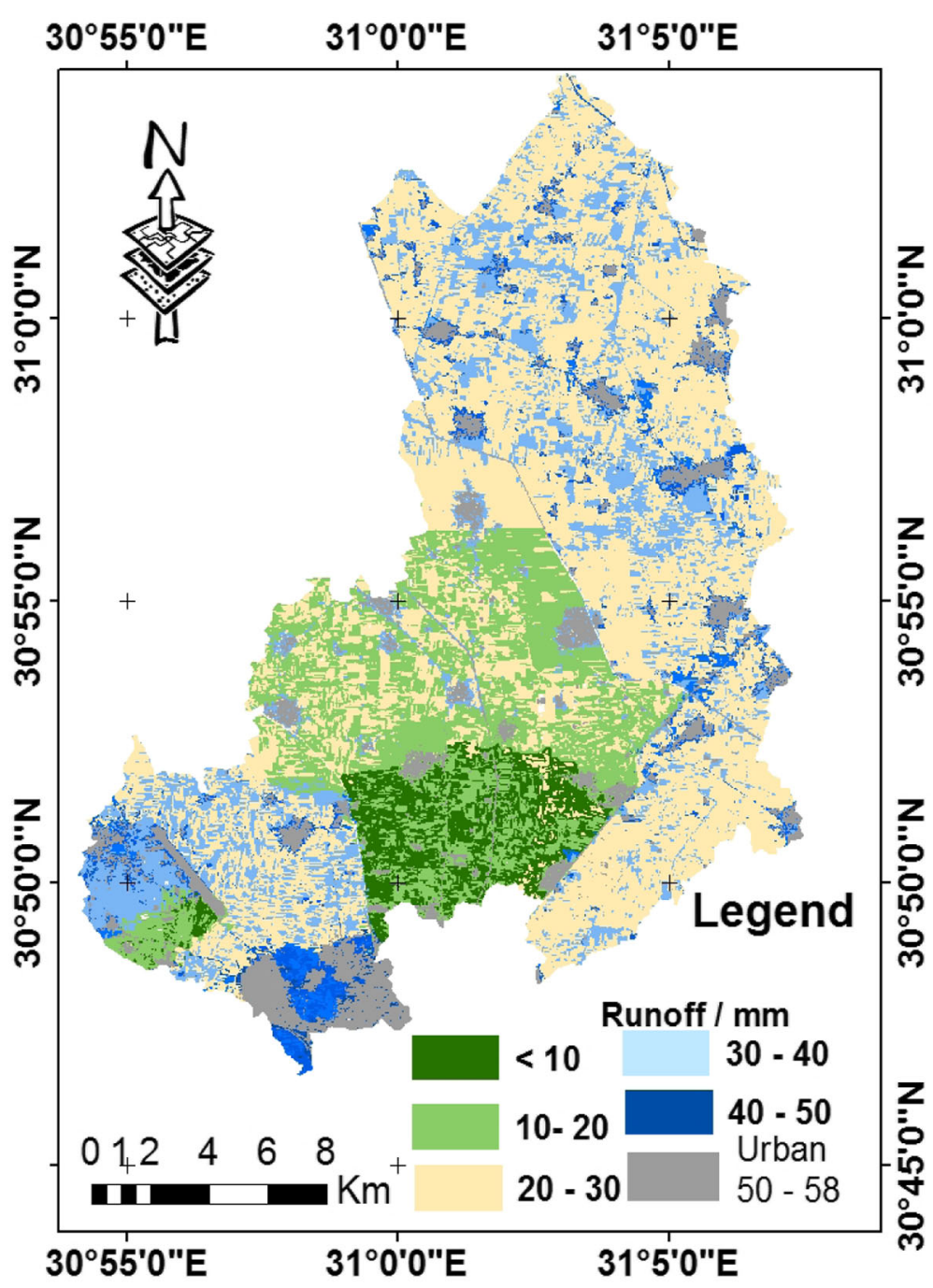

Fig. 7 Spatial distribution of runoff values for a rainfall of $58 \mathrm{~mm} / \mathrm{m}^{2}$ 
activities in cultivated soils result in increasing the tendency of the surface runoff with the possibility of climate change and increase precipitation.

\section{Conclusions}

Applying the NRCS-CN model combined with the GIS technique for analyzing the direct surface runoff at a catchment scale can be an efficient tool in the context of the demand for forecasting and projection the hydric hazards. The strengths of these scenarios using this model are the precisely, possibility, and rapidity of the obtaining results to simulate the hydric surface runoff either on a daily, monthly, seasonal base, or on an annual scale. Increasing the urban activities in arable lands would result in increasing the tendency of these soils for a surface runoff with the possibility of climate change. In addition, the results illustrated that the highest value of surface runoff was pronounced around the urban areas $50-58 \mathrm{~mm}$ as a result of paved surfaces and rooftops that did not allow water to penetrate into the soil. Otherwise, the lower runoff values ranged between 30 and $40 \mathrm{~mm}$ in the cropland area located in the north of the study area. Thus, precise water management practices could be applied to find the most efficient technology to save water and convey it to the drought regions. Nevertheless, the identified drawback in this model that ignoring certain parameters such as evapotranspiration. Remote sensing data provides several essential information about land use/land cover and the topographic factors; therefore, integrating these data with soil characteristics using GIS techniques can be used to model the surface runoff based on spatial hydrological modeling.

\section{Abbreviations \\ DEM: Digital elevation model; GIS: Geographic information system; GPS: Global poison system; HRU: Hydrologic response units; HSG: Hydrologic soil group; LULC: Land use/land cover; NRCS-CN: Natural resource conservation service curve number model; SVM: Support vector machine}

\section{Acknowledgements}

The authors would like to thank the soil department of National Authority for Remote Sensing and Space Sciences (NARSS) for facilitating during this work.

\section{Authors' contributions}

All authors contributed to the manuscript idea. MES, BAA and AM, the field measurements.AM analyzed the data. MES and BAA mapped the production. The manuscript was written by MES and AM. The manuscript was reviewed by $A A B$. All authors read and approved the final manuscript.

\section{Funding}

Not applicable

\section{Availability of data and materials}

Not applicable.

Ethics approval and consent to participate Accepted
Consent for publication

Accepted.

\section{Competing interests}

The authors declare that they have no competing interests.

\section{Author details}

${ }^{1}$ National Authority for Remote Sensing and Space Sciences (NARSS), Cairo, Egypt. ${ }^{2}$ Soil Science Department, Faculty of Agriculture, Zagazig University, Zagazig, Egypt.

Received: 9 April 2019 Accepted: 12 November 2019

Published online: 12 December 2019

\section{References}

AbdelRahman MA, Shalaby A, Mohamed ES (2019) Comparison of two soil quality indices using two methods based on geographic information system. Egypt J Remote Sensing Space Sci 22(2):127-136

Abu-hashim M, Mohamed ES, Belal AA (2015) Identification of Potential Soil Water Retention using Hydric Numerical Model at Arid Regions by Land-use Changes. Int Soil Water Conserv Research. https://doi.org/10.1016/j.iswcr. 2015.10.005

Abu-Hashim, M.S.D. (2011). Impact of land-use and land management on wate infiltration capacity on a catchment scale. PhD Thesis Fakultat Architektur. Bauingeniurwesen und Umweltwissenschaften der Technischen Universitat Carolo-Wilhelmina zu Braunschweig, Germany.

Agnihotri IIA, Punia MP and Sharma JR (2017) Estimation and assessment of spatial variations in water availability in west flowing river basin of Kutch, Saurashtra and Marwar (WFR-KSM basin) using geospatial technology. Int J Adv Remote Sensing GIS 6(1):1994-2000

Belal AA, El-Ramady HR, Mohamed ES, Saleh AM (2014) Drought risk assessment using remote sensing and GIS techniques. Arabian J Geosciences 7(1):35-53

Belal AA, Mohamed E, Saleh A, Jalhoum M (2019) Soil Geography. In: The Soils of Egypt (pp. 111-136). Springer, Cham

Dunne T, Leopold LB (1978) Water in environmental planning. W. H. Freeman Co. , San Francisco, p 818

Elkhrachy I (2015) Flash flood hazard mapping using satellite image and GIS tools: a case study of Najran city, Kingdom 306 of Saudi Arabia KSA. Egypt J Remote Sens Space Sci. 18(2):261-278. https://doi.org/10.1016/j.ejrs.2015.06. 007

El-Zeiny A, El-Kafrawy S (2017) Assessment of water pollution induced by human activities in Burullus Lake using Landsat 8 operational land imager and GIS. Egypt J Remote Sensing Space Sci 20:S49-S56

Gad, A. A., \& El-Zeiny, A. (2016). Spatial analysis for sustainable development of El Fayoum and Wadi El Natrun desert depressions, Egypt with the aid of remote sensing and GIS. Journal of Geography, Environment and Earth Science International, 1-18.

Hammam AA, Mohamed ES (2018) Mapping soil salinity in the East Nile Delta using several methodological approaches of salinity assessment. Egypt J Remote Sensing Space Sci. https://doi.org/10.1016/j.ejrs.2018.11.002

Hawkins RH (1993) A symptotic determination of runoff curve numbers from data. J Irrig Drain 15 E.-ASCE 119(2):334-345

Hawkins, R.H., Ward, T.J., Woodward, D.E., \& Van Mullem, J.A. (2009). Curve Number Hydrology: State of the practice. Rev. Ed., U.S.D.A., Washington D.C., U.S.A.

Hendawy E, Belal AA, Mohamed ES, Elfadaly A, Murgante B, Aldosari AA, Lasaponara R (2019) The prediction and assessment of the impacts of soil sealing on agricultural land in the North Nile Delta (Egypt) using satellite data and GIS modeling. Sustainability 11(17):4662

Klute A (1986) Water retention: Laboratory methods. In: Klute, A. (Ed). Methods of soil analysis. Part 1. 2nd edition. Agronomy Monograph 9, pp 635-662. ASA and SSSA, Madison, WI. Phys Chem Earth 28:1377-1387

Latha M., M. Rajendran, A. Murugappan (2012) Comparison of GIS based SCS-CN and strange table method of rainfall-runoff models for Veeranam Tank, Tamil Nadu, India. International Journal of Scientific \& Engineering Research, Volume 3, Issue 10, October-2012 1 ISSN 2229-5518

Li X, Niu J, Xie B (2014) The effect of leaf litter cover on surface runoff and soil erosion in Northern China. PloS one 9(9):e107789

Michel C, Andréassian V, Perrin C (2005) Soil conservation service curve number method: how to mend a wrong soil moisture accounting procedure. Water Resour Res 41:W02011. https://doi.org/10.1029/2004WR003191 
Mishra SK, Singh VP (1999) Another look at SCS-CN method. J Hydrol E.-ASCE 4(3):257-264

Mohamed ES (2013) Spatial assessment of desertification in north Sinai using modified MEDLAUS model. Arabian J Geosciences 6(12):4647-4659

Mohamed ES, Abu-hashim M, AbdelRahman MA, Schütt B, Lasaponara R (2019) Evaluating the effects of human activity over the last decades on the soil organic carbon pool using satellite imagery and GIS techniques in the Nile Delta Area, Egypt. Sustainability 11(9):2644

Mohamed ES, Belal A, Shalaby A (2015) Impacts of soil sealing on potential agriculture in Egypt using remote sensing and GIS techniques. Eurasian Soi Sci 48(10):1159-1169

Mohamed ES, Saleh AM, Belal AA (2014) Sustainability indicators for agricultural land use based on GIS spatial modeling in North of Sinai-Egypt. Egypt J Remote Sensing Space Sci 17(1):1-15

Mohamed ES, Schütt B, Belal A (2013) Assessment of environmental hazards in the north western coast-Egypt using RS and GIS. Egypt J Remote Sensing Space Sci 16(2):219-229

Morgan RPC (2001) A simple approach to soil loss prediction: a revised MorganMorgan-Finney model. Catena 44(4):305-322. https://doi.org/10.1016/ S03418162(00)00171-5

MWRIE Ministry of Water Resources and Irrigation, Egypt (2014). Water scarcity in Egypt. Report 1-5. http://www.mfa.gov.eg/SiteCollectionDocuments/Egypt\%2 OWater\%20Resources\%20Paper_2014.pdf.

Soulis KX, Valiantzas JD, Dercas N, Londra PA (2009) Analysis of the runoff generation mechanism for the investigation of the SCS-CN method applicability to a partial area experimental watershed. Hydrol Earth Syst Sci Discuss. 6:373-400

Wahren A, Feger K.H, Schwärzel K, and Münch A (2009) Land-use effects on flood generation - considering soil hydraulic measurements in modelling, Adv. Geosci., 21, 99-107, https://doi.org/10.5194/adgeo-21-99-2009.

\section{Publisher's Note}

Springer Nature remains neutral with regard to jurisdictional claims in published maps and institutional affiliations.

\section{Submit your manuscript to a SpringerOpen ${ }^{\circ}$ journal and benefit from:}

- Convenient online submission

- Rigorous peer review

- Open access: articles freely available online

High visibility within the field

- Retaining the copyright to your article

Submit your next manuscript at $\boldsymbol{\nabla}$ springeropen.com 